\title{
Executive Compensation and Earnings Management
}

\author{
-An Empirical Study of Manufacturing Industry
}

\author{
Chan Lyu, Chao Zhang \\ School of Business, Macau University of Science and Technology, Macau
}

\begin{abstract}
Based on the management compensation contract and related theory of earnings management, this paper selects 480 listed A share manufacturing companies in Shanghai and Shanghai Stock Exchange from 2010 to 2014 as sample data, and takes executive monetary compensation and executive shareholding as proxy variables of executive compensation incentive mechanism. We use the absolute value of residuals estimated from modified Jones model to measure the magnitude of earnings management. This study finds a positive correlation between monetary compensation and earnings management. By contrast, the long-term equity compensation incentive has a negative link with earnings management. The combination of long-term and short-term incentive compensation has an inhibitory effect on earnings management. Moreover, this paper illustrates some suggestions for these existing problems.
\end{abstract}

Keywords-Executive compensation; Management shareholding; Incentives mechanism; Earnings management

\section{INTRODUCTION}

The compensation system in corporate governance has long been considered as a powerful tool to motivate employees, and the compensation is often linked to business performance. In recent years, the listed companies develop rapidly with the growth of the capital market; however, over-manipulation of earnings management has also become increasingly fierce. Since the 1990s, the modern enterprise system has been regarding the maximization of shareholder value as the ultimate goal of corporate financial management. However, there is a certain departure between the principal-agent theory and this goal. The reason is that, managers look to further increase their own interests to some extend, especially under the background of the separation between management right and ownership. This is the main reason for the above departure phenomenon. As described in Executive Compensation Survey of 2013-2014 for A-share Listed Companies and based on the different incentive tools adopted by listed companies during this period, a balanced distribution is presented and the listed companies adopting compound incentive measures, such as stock option and restricted stock, etc., increase significantly[1]. Compared with the traditional single monetary compensation incentive mechanism, listed companies are more and more inclined to combine executives' annual compensation with the stock incentive in order to maximize the benefits of enterprises nowadays.

Therefore, this paper will discuss about the relationship between executive compensation and earnings management and the impact thereof in an in-depth manner, and conduct the

Corresponding author: Chan Lyu (1985-), assistant professor, School of Business, Macau University of Science and Technology, Macau.

chlyu@must.edu.mo study from the aspects of monetary compensation and the stock held by executives with a combination of effects of the two, so as to provide useful suggestions on the compensation incentive structure adjustment and the corporate governance of listed companies and, hopefully, to promote the healthy development of the capital market in the future.

\section{LITERATURE REVIEW}

\section{A. Related literature of earnings management}

K. Schipper, an American accounting scholar, argues that earnings management is a "disclosure management" to purposefully intervene in external financial reports so as to pursue personal gain in business activities [2]. The study of Chinese scholars on earnings management is later than that of the West. Jianqiao Lu defined earnings management as the purposeful accounting policy selection and accounting estimate change by the manager for achieving maximization of their utility and the corporate value, which is premised on not violating accounting standards [3].

Most foreign researchers analyse the earnings management in view of future earnings performance. Western scholars Watts and Zimmerman put forward Positive Accounting Theory three hypotheses, namely, the management compensation hypothesis (bonus plan hypothesis), the debtequity hypothesis and the political cost hypothesis [4]. The compensation incentive mechanism is a dual mechanism that can motivate the executives to be in line with the shareholders' interests and to pursue maximization of their own interests. Therefore, under the effect of interest induction, to avoid risks and information asymmetry, the incentive for executives to manipulate earnings information in external accounting reports is significantly enhanced. Debt contracts of enterprises present executives the incentive to adjust accounting indexes and accounting reports so as to avoid the restrictions of creditors on their management practices. According to the characteristics of the modern securities market, western scholars believe that, stock issuers will not adjust their current yield arbitrarily before issuing to provide a low and long-term stock yield and net profits in the future, and such earnings manipulation is less likely to occur in companies that do not issue stock [5].

Due to China's special national conditions and the situation that state-owned shares hold the absolute superiority in the shareholding structure, the study on the incentive of earnings management at home is obviously different from that of foreign countries, and the former takes loss avoidance as an important incentive. By studying samples of listed companies 
from 1995 to 2003, Yaping Wang et al. found that, on the premise that the earnings information conforms to the mixed normal distribution hypothesis, these listed companies did manipulate the earnings in order to avoid the reported loss [6]. Guangyong Lei, Huilong Liu and Weidong Zhang et al. found that there is earnings management behaviour before and after the issuance of stocks, due to the earnings management incentive of IPO, stock allotment and additional stock issuance [7-8]. Zhenwei $\mathrm{Gu}$ and Lingnan Ouyang observed the distributions of return on equity and return on total assets are accessible to the frequency distribution method and found that most a-share companies manipulate the earnings in order to achieve the passing scores of stock allotment [9].

\section{B. Related literature of executive compensation}

The executive compensation incentive model generally can be divided into short-term compensation incentive and longterm compensation incentive. The short-term compensation mainly is monetary compensation, while the long-term compensation mainly is non-monetary compensation. In order to comprehensively consider executive compensation, this paper selects the top three highest-paid executives' compensation to measure this variable for monetary compensation. However, due to restrictions on information disclosure of perquisite consumption, for example, to listed companies, as for non-monetary compensation, this paper only selects the executives' shareholding proportion for measurement.

The level of executive compensation is influenced by many factors, and these factors are generally divided into three categories: personal factors of these executives, corporate governance and other external factors. First of all, judged from the talents selection criteria of the market, it's found managers with higher education background, professional skills and work experience are more prominent in the market. Xinyuan Chen and Donghua Chen pointed out that state-owned enterprises have significantly higher compensation than non-state-owned enterprises, but are also more likely to have compensation regulation issues. In particular, the compensation regulation degree is relatively high for centrally-administered enterprises and government enterprises [10]. In addition, some laws and regulations issued by the country, such as labour law, tax law and law on the protection of employees' rights and interests, etc., will affect the corporate compensation system. Industries and geographical differences will also result in income gaps.

From the perspective of monetary compensation, Healy [11], a western scholar, is the first one to find that managers will maximize their personal benefits through earnings manipulation under a bonus incentive system. Yanxi Li, Shize Bao, and Rui Gao et al. found that there is a significant and positive correlation between the executive compensation and operational accrued profits in listed companies [12]. Yuhui Wu and Shinong $\mathrm{Wu}$ et al. proved that accounting performance and agency costs are significantly and positively related to executive compensation, while corporate value and shareholder returns are not significantly and positively related to executive compensation [13]. Therefore, hypothesis H1 is proposed: there is a significant and positive correlation between executives' monetary compensation and earnings management, i.e., monetary compensation incentive induces earnings management.

From the perspective of shareholding ratio, Jensen and Heckling's research [14] shows that, with the increase of stock held by executives, their interests tend to be in line with the interests of shareholders, causing the incentive of earnings management be weakened. By increasing the stock held by executives, stock incentive transfers the residual claims, enhances the control and restraint of the executives and alleviates the incentive of earnings management [15]. The empirical study of Shuqiang Cheng [16] shows that, the stock proportion held by institutional investors is negatively related to earnings management; moreover, the higher the proportion is, the more enhanced the accounting information authenticity is, and the more the earnings manipulation is inhibited. Therefore, hypothesis $\mathrm{H} 2$ is proposed: there is a significant and negative correlation between the shareholding ratio of executive and the earnings management, i.e., the listed company can use stock incentive to inhibit the earnings management behaviour.

$\mathrm{Xi}$ Zhao and Yupeng Du believe that, stock held by executives and executive compensation sensitivity are negatively correlated. The reason is that, the higher the stock proportion held by executives, the lower the degree of entrusted agency relationship and the fewer the earnings management incentive induced by compensation decrease [17]. Therefore, hypothesis H3 is proposed: for the listed company adopting stock incentive, the executive shareholding ratio and monetary compensation have a combined restraining effect on the earnings management behaviour.

\section{STUDY DESIGN}

\section{A. Sample selection and data sources}

This paper selects 480 Shanghai a-share listed companies between the year of 2010 and 2014 as the primary sample. Since the year of 2010, the operating conditions of listed companies typically reflect China's economic conditions to certain degrees. The executives with the highest compensation and the fastest compensation growth are from a-share listed companies of Shenzhen main board, while the executive compensation from companies of Shanghai main board remains stable. Moreover, analysing within the same industry can minimize the estimated parameters error as much as possible. The data are all from the CSMAR database, excluding data of: ST or *ST and newly listed companies; companies with incomplete financial data; and specially extreme cases such as companies with significant risks disclosed in their audit reports.

\section{B. Test model}

In this paper, we establish a multivariate regression model to conduct empirical research on the relationship among executive compensation, executive shareholding proportion and earnings management, so as to verify the above assumptions.

To verify these assumptions, the following model is established: 


$$
\mathrm{DA}=\beta_{0}+\beta_{1} S A L+\beta_{2} M S R+\beta_{3} S A L * M S R+\beta_{4} S I Z E+\beta_{5} D E B T+\beta_{6} R O A+\beta_{7} A G E+\epsilon
$$

Wherein, DA is the degree of earnings management of listed companies, and the Jones model are adopted for estimation. Considering the experience of previous study, this paper adopts total assets at the end of year t- 1 to adjust the variables, so as to narrow the ranges of values. Lijun Xia and

$$
\begin{gathered}
T A_{i, t} / A_{i, t-1}=\beta_{1} / A_{i, t-1}+\beta_{2}\left(\Delta \text { Sale }_{i, t} / A_{i, t-1}\right)+\beta_{3}\left(F A_{i, t} / A_{i . t-1}\right)+\beta_{4}\left(C F O_{i, t} / A_{i . t-1}\right)+\mu_{i, \square} \\
N D A_{i, t} / A_{i, t-1}=\beta_{1} / A_{i, t-1}+\beta_{2}\left(\Delta \text { Sale }_{i, t} / A_{i, t-1}\right)+\beta_{3}\left(F A_{i, t} / A_{i . t-1}\right)+\beta_{4}\left(C F O_{i, t} / A_{i . t-1}\right) \\
D A_{i, t}=T A_{i, t} / A_{i, t-1}-N D A_{i, t} / A_{i, t-1}
\end{gathered}
$$

Wherein, $\mathrm{TA}_{\mathrm{i}}, \mathrm{t}$ is the total accrued profits of company $i$ in period $t ; A_{i}, t-1$ is the total assets of period $t-1$; Sale $i, t$ is the difference of main business income in period $t$ and the main business income in period $t-1 ; F_{i, t}$ is the original value of the fixed assets of the period $t$; $\mathrm{CFO}_{i, t}$ is the net cash flow from operating activities during period $t$.

In model (1), considering the disclosure scope of the annual report of listed companies, for the executive monetary compensation (SAL), this paper selects the natural logarithm of "the total of the top three executive compensations" as the proxy variable of executive compensation. As a means to measure the level of stock incentive, management shareholding ratio (MSR) is calculated as the ratio of the total number of shares held by the executives at the end of the year to the total stock issue of the company.

According to the evidence of previous study, there are many other factors that affect the earnings management of listed companies. When studying the explanatory variables and explained variables, the following control variables are mainly added: corporate size (SIZE), asset-liability ratio (DEBT), net profit rate of assets (ROA), and listing age (AGE). The definitions of the above variables and the calculation processes are shown in Table 1.

TABLE I. SUMMARY TABLE OF VARIABLE DEFINITION

\begin{tabular}{cc}
\hline Type of variable & Name of variable \\
\hline Explained variable & Earnings management degree (EM) \\
Explained variable & Natural algorithm of executive monetary \\
& compensation (SAL) \\
Management shareholding ratio (MSR) & Corporate size (SIZE) \\
Control variable & Asset-liability ratio (DEBT) \\
& Net profit rate of assets (ROA) \\
Listing age (AGE)
\end{tabular}

\section{EMPIRICAL ANALYSIS}

\section{A. Descriptive statistics and correlation analysis}

In order to avoid the influence of the abnormal value of the variables on the research results in the follow-up study, a winsorized treatment of $1 \%$ is conducted on the continuous variables. As can be seen from the descriptive statistics of variables in Table 2, among the 1716 sample data, the maximum value of earnings management degree is 3.1130 and the minimum value is 0 . Some common earnings management behaviours in these enterprises are shown. The annual executive compensations from $50 \%$ of these companies are

Description of variable
Absolute value of manipulated accrued profits after the end-of-
period assets adjustment
SAL=LN (the total of the top three executive monetary
compensations)
MSR=Total number of shares held by the executives at the end
of year/Total stock issue
Natural algorithm of total corporate assets
DEBT=Liabilities at the end of the year/Assets at the end of the
ROA=Net profits $\div$ Total average assets $\times 100 \%$
The first listed year is shown as "0", the second listed year is
shown as "1", and so on.

higher than the average annual compensation, and the maximum value and the minimum value are far apart. There is a sharp contrast between the sky-high compensation and the almost zero compensation. Combined the information of Table 2 and Table 3, it is shown that the average shareholding ratio of executives is $0.86 \%$. Over $40 \%$ of the executives hold 0 stock, and the stock held by over $80 \%$ of the executives is far below the average. In conclusion, from the management incentive point of view, it can be seen from both the executive compensation and the executive shareholding ratio that the sample companies show great differences in the compensation mechanism.

TABLE II. DESCRIPTIVE STATISTICS OF VARIABLES

\begin{tabular}{cccccc}
\hline & Minimum value & Maximum value & Mean value & Median & Standard deviation \\
\hline EM & 0.0000 & 2.5770 & 0.0524 & 0.0288 & 0.1187 \\
SAL & 0.5977 & 3.3927 & 2.0978 & 2.1057 & 0.3221 \\
MSR & 0.0000 & 0.4353 & 0.0086 & 0.0000 & 0.0425 \\
SIZE & 17.0487 & 26.7512 & 22.2379 & 22.1265 & 1.3142 \\
DEBT & 0.0351 & 12.1274 & 0.5340 & 0.5156 & 0.4248 \\
ROA & -0.8401 & 2.6772 & 0.0358 & 0.0263 & 0.1130 \\
AGE & 2.0000 & 24.0000 & 12.7900 & 13.0000 & 4.4020 \\
\hline
\end{tabular}


TABLE III. QUINTILE OF EXECUTIVE SHAREHOLDING RATIO

\begin{tabular}{lll}
\hline Quintile & $20 \%$ & .000000 \\
\hline & $40 \%$ & .000000 \\
& $60 \%$ & .000998 \\
& $80 \%$ & .038542 \\
\hline
\end{tabular}

Table 4 shows the correlation analysis of the variables. It can be seen that all the variables, except the control variable (AGE), are significantly related to the earnings management,

and variables, except the shareholding ratio (MSR) and the corporate size (SIZE), are positively related to the earnings management.

TABLE IV. CORRELATION TEST OF VARIABLES

\begin{tabular}{|c|c|c|c|c|c|c|c|c|}
\hline & & EM & SAL & MSR & SIZE & DEBT & ROA & AGE \\
\hline \multirow[t]{2}{*}{ EM } & Person-related & 1 & $0.102 * * *$ & $-0.113 * * *$ & $-0.137 * * *$ & $0.182^{* * *}$ & $0.502 * * *$ & 0.003 \\
\hline & $\begin{array}{l}\text { Significance } \\
\text { (2-tailed) }\end{array}$ & & 0.000 & 0.000 & 0.000 & 0.000 & 0.000 & 0.915 \\
\hline \multirow[t]{2}{*}{ SAL } & Person-related & $0.102 * * *$ & 1 & $0.067 * * *$ & -0.020 & $-0.058 * *$ & $0.040 *$ & $-0.238 * * *$ \\
\hline & & 0.000 & & 0.006 & 0.412 & 0.017 & 0.096 & 0.000 \\
\hline \multirow[t]{2}{*}{ MSR } & Person-related & $-0.113 * * *$ & $0.067 * * *$ & 1 & $0.481 * * *$ & $-0.164 * * *$ & $0.123 * * *$ & -0.022 \\
\hline & $\begin{array}{l}\text { Significance } \\
\text { (2-tailed) }\end{array}$ & 0.000 & 0.006 & & 0.000 & 0.000 & 0.000 & 0.354 \\
\hline \multirow[t]{2}{*}{ SIZE } & Person-related & $-0.137 * * *$ & -0.020 & $0.481 * * *$ & 1 & -0.029 & 0.009 & $-0.079 * * *$ \\
\hline & $\begin{array}{l}\text { Significance } \\
\text { (2-tailed) }\end{array}$ & 0.000 & 0.412 & 0.000 & & 0.223 & 0.714 & 0.001 \\
\hline \multirow[t]{2}{*}{ DEBT } & Person-related & $0.182 * * *$ & $-0.058 * *$ & $-0.164 * * *$ & -0.029 & 1 & $-0.246 * * *$ & 0.025 \\
\hline & $\begin{array}{l}\text { Significance } \\
\text { (2-tailed) }\end{array}$ & 0.000 & 0.017 & 0.000 & 0.223 & & 0.000 & 0.294 \\
\hline \multirow[t]{2}{*}{ ROA } & Person-related & $0.502 * * *$ & $0.040^{*}$ & $0.123 * * *$ & 0.009 & $-0.246 * * *$ & 1 & -0.027 \\
\hline & $\begin{array}{l}\text { Significance } \\
\text { (2-tailed) }\end{array}$ & 0.000 & 0.096 & 0.000 & 0.714 & 0.000 & & 0.262 \\
\hline \multirow[t]{2}{*}{ AGE } & Person-related & 0.003 & $-0.238 * * *$ & -0.022 & $-0.079 * * *$ & 0.025 & -0.027 & 1 \\
\hline & $\begin{array}{l}\text { Significance } \\
\text { (2-tailed) }\end{array}$ & 0.915 & 0.000 & 0.354 & 0.001 & 0.294 & 0.262 & \\
\hline
\end{tabular}

a. Note: $* * *$ represents significance of $1 \%$, ** represents significance of $5 \%$, while * represents significance of $10 \%$.

\section{B. Analysis of regression results}

Table 5 shows that there is a positive correlation between executive monetary compensation and earnings management $(\beta$ $=0.347, \mathrm{t}=5.001)$, which shows that there is earnings management behaviour induced by incentive of the executive compensation. There is a negative correlation between executive shareholding ratio and earnings management $(\beta=-$ $0.037, \mathrm{t}=-4.450)$, i.e., the executives will reduce the earnings management degree when the number of shares held by them increases. The reason is that, the executives are no longer mere operators, but begin to change to a combined role of owners and operators. When their personal interests are linked with the interests of shareholders, the executives will restrain their earnings management behaviours so as to avoid harming their interests. In addition, the correlation coefficient of $\mathrm{M} * \mathrm{SAL}$ is significantly negative $(\beta=-0.005, \mathrm{t}=-2.019)$, which verifies that the higher the executive shareholding proportion, the lower the correlation between executive compensation and earnings management. In other words, under the circumstances that the stock incentive mechanism is enhanced, the monetary compensation is less likely to induce earnings management.

Among the control variables, there is a negative correlation between corporate asset size and earnings management. From a political cost point of view, a reasonable explanation can be given: when the corporate asset size expands, the possibility that the current earnings will be decreased when the government regulation is loosened up is enhanced. The coefficients of asset-liability ratio (DEBT) and net profit rate of assets (ROA) are all positive, and are significantly correlated with earnings management at level of $1 \%$, showing that executives' incentive from their own interests will trigger earnings management bahaviour. The value $\mathrm{P}$ of the listing age (AGE) is 0.933 and there is no significance test passing $10 \%$ significance level, so its correlation with earnings management is not significant. 
TABLE V. REgRESSION ANALysis of EXECUTIVE MONETARy COMPENSATION, SHAREHOLDING RATIO ANd EARNings MANAGEMENT

\begin{tabular}{cccc}
\hline Variable & Regression coefficient & Value T & Value P \\
\hline Constant & $0.211^{* * *}$ & 5.294 & 0.000 \\
SAL & $0.347^{* * *}$ & 5.001 & 0.000 \\
MSR & $-0.037^{* * *}$ & -4.450 & 0.000 \\
M*SAL & $-0.005^{*}$ & -2.019 & 0.089 \\
SIZE & $-0.007^{* * *}$ & -3.667 & 0.000 \\
ROA & $0.618^{* * *}$ & 29.919 & 0.000 \\
DEBT & $0.087^{* * *}$ & 15.769 & 0.000 \\
AGE & 0.001 & 1.213 & 0.225 \\
\hline Note: ${ }^{* * *}$ represents significance of $1 \%, * *$ represents significance of $5 \%$, while * represents significance of $10 \%$.
\end{tabular}

\section{CONCLUSIONS AND RECOMMENDATIONS}

Most of China's listed companies adopt annual compensation system, which can measure the corporate performance with profit indexes such as net profit rate of assets; however, the accounting profits reflect the short-term operating results and can be easily manipulated. Monetary compensation is one of the basic incentives for earnings management. Stock incentive has an inhibiting effect on earnings management. When listed companies adopt the stock incentive, the influence of the compensation incentive and the earnings management declines, showing that listed companies hasnot comprehensively considered the impact of the monetary incentive and the stock incentive on the earnings management when stipulating the executive compensation contract, the compensation system of China's listed companies is still imperfect, and the agency issue damaging the interests of shareholders in the pursuit of personal interests is still serious.

Therefore, enterprises should pay more attention to the scientific rationality of the performance of evaluation model, reduce the impact on the earnings management due to compensation contract, and change the current over-reliance on the profit indexes to achieve the diversification of linked indexes. Generally, the compensation incentive system in China is relatively homogenized, and long-term stock incentive is rare. Therefore, the listed companies shall pay more attention to the role of stock incentive and increase the executive shareholding proportion, so as to generate a long-term impact by the executives' behaviour on corporate development, to give full play to the role of stock incentive and combine the shortterm and long-term compensation incentives.

\section{ACKNOWLEDGEMENT}

This study is subsidized by Macao Foundation.

\section{REFERENCES}

[1] Deloitte \& Touche. Executives compensation of China's a-share listed companies of 2013-2014 [R]. Shanghai: 2014.

[2] MARAIS L, SCHIPPER K, SMITH A. Wealth effects of going private for senior securities [J]. Journal of Financial Economics, 1989, 23(1): 155-191.

[3] Jianqiao Lu. An empirical study of earnings management of China's loss-making listed companies [D]. Shanghai: Shanghai University of Finance and Economics, 1998.
[4] WATTS R L, ZIMMERMAN J L. Towards a positive theory of the determination of accounting standards[J]. Accounting review, 1978: 112-134.

[5] TEOH S H, WELCH I, WONG T J. Earnings management and the long - run market performance of initial public offerings[J]. The Journal of Finance, 1998, 53(6): 1935-1974.

[6] Yaping Wang, Liansheng $\mathrm{Wu}$, and Yunxia Bai. Management and amplitude of earnings management of China's listed companies [J]. Economic Research, 2005 (12): 102-112.

[7] Guangyong Lei, and Huilong Liu. Control of large shareholder , financing scale and degree of earnings manipulation [J]. Management World, 2006 (1): 129-136.

[8] Weidong Zhang. Refinancing options for listed companies: stock allotment, public issuance and private issuance of new shares? [J]. Economic Review, 2008 (6): 71-81.

[9] Zhenwei Gu, Lingnao Ouyang. On the motive for earnings management in listed companies in China and a Empirical study thereof [J]. Journal of Northeastern University (Social Science), 2008,10(2): 139-144.

[10] Xinyuan Chen, Donghua Chen, and Hualin Wan et al. Regional difference, compensation regulation and executive corruption [J] Management World, 2009 (11): 130-143.

[11] HEALY P M, WAHLEN J M. A review of the earnings management literature and its implications for standard setting[J]. Accounting horizons, 1999, 13(4): 365-383.

[12] Yanxi Li, Shize Bao, Rui Gao et al. Compensation incentive, board monitoring and earnings management of listed companies [J]. Nankai Business Review, 2007,10(6): 55-61.

[13] Yuhui Wu and Shinong Wu. Research on self-interested behaviour of enterprise executives and its influencing factors - based on the evidence of stock incentives draft for listed companies in China [J]. Management World, 2010 (5): 141-149.

[14] JENSEN M C, MECKLING W H. Theory of the firm: Managerial behaviour, agency costs and ownership structure[J]. Journal of financial economics, 1976, 3(4): 305-360.

[15] Weiying Zhang and Chujun Liu. Game theory and information economics [M]. Maochang, 1999.

[16] Shuqiang Cheng. An empirical study on the relationship between institutional investors' shareholdings and accounting earnings information of listed companies [J]. Management World, 2006.

[17] Xi Zhao and Yupeng Du. Impact of corporate governance on the sensitivity of executive compensation incentive [J]. Soft Science, 2009,23(11): 92-95.

[18] Lijun Xia. Study on earnings management measurement model application in China stock market [J]. China Accounting and Finance Review, 2003, 5(2): 94-154.

[19] Qiliang Liu, Weifeng He and Le Luo. Mandatory adoption of IFRS, new law enforcement and accrued and true earnings management [J]. China Accounting and Finance Review, 2011, 13(1): 57-121. 